\title{
Freight Carrier`s Liability under the CMR convention 1956
}

\author{
Ian Quigley*
}

\section{Foreword}

Legal certainty has always been essential to the smooth functioning of all areas of business endeavour, and this article shall attempt to explain how the CMR Convention [1956] brings this all important certainty to one aspect of business; namely: the International Transport of Goods by Road. Before going on to explain in a little more detail what the CMR Convention is and how it works; it is sufficient to say that it, as far as this is possible, locates the point in time at which loss or damage to the goods in transit occured; imposes [and from 1978; sets upper limits] responsibility on the carrier [in whose custody the goods were when the damage or loss happened] to make good this loss.

\section{Carriage of items not covered by the CMR Convention.}

However, the CMR Convention is limited to the carriage of goods; Article 1 of the Convention states that it cannot be applied to the international carriage of: inter alia; mail, personal effects, explosives/explosive materials, or corpses. Items not covered by the CMR Convention come under the protection of other regulations. For instance, the Carriage of Dangerous Goods by Road can only be performed in strict accordance another international agreement called the ADR Convention. This Convention stipulates that dangerous cargoes may only be carried on lorries specially constructed and equipped for the carriage of the particular type of dangerous goods in question. Furthermore, according to the ADR Convention, the carriage of dangerous goods may only be performed subject to the condition that the driver has the relevant and valid certification which permits him to handle and transport such dangerous cargoes.

Responsibility for the declaration, in the regulation manner, of the dangerous goods; and the adequate packing of same, complete with internationally prescribed and recognised markings and symbols, rests with the consignor.

\section{What is the CMR Convention?}

It is a United Nations document from 1956 and it forms, to a great extent, the legal framework facilitating the International Transport of Goods By Road. Since its coming into effect in 1956 there has only been one improvement made to it; the 1978 Amendment, which, as mentioned in the foreword, sets an upper limit on the given carrier's liability for loss and/or damage to goods entrusted to him for carriage.

* Ian Quigley, B.A.LL.B.; Senior Assistant at the Department of English, Faculty of International Relations, The University of Economics, Prague. 
In order to appreciate just how useful an instrument the CMR Convention is to the carriage of goods by road, one need only look at the situation before 1956, or indeed today in the states which are not signed up to the CMR Convention; long, expensive litigation just to apportion the blame for, and extent of, loss and/or damage; not to mention fixing a just sum of compensation for the injured party.

Czechoslovakia signed up to it in 1974; however, neither Czechoslovakia, nor, to date, the Czech Republic have signed the 1978 Amendment to the convention.

This year, 2006, is the $50^{\text {th }}$ Anniversary of the CMR Convention, and it speaks volumes that, despite the changes, great and small, which have taken place over the decades in: business practice, finance, customs clearance and freight handling procedures, and the development of multi-modal carriage; there have not been found any real defects in the convention. Although it is a UN convention, its provisions have a tremendous impact on the functioning of the European Union's internal market; just think of its effect on the free movement of goods.

\section{When could the CMR Convention apply?}

The CMR Convention covers the carriage of goods by road when carriage is performed between two or more countries, one of which is a signatory of the CMR Convention.

\section{How does the CMR Convention work in practice?}

Firstly, all the relevant details relating to each consignment; i.e. amount and type of goods, financial value of same, the necessary conditions for safe storage of the goods during transit, [this last mentioned would apply in the case of perishables], the condition the goods are in when they are handed over for carriage, etc; are entered in a special document called a CMR Consignment Note [in some countries:: Waybill]. Whatever name it is known by, its form is prescribed by the CMR Convention and must not be changed. In addition to the above-mentioned details, the document also contains; and serves as evidence of; the terms of carriage relating to each consignment which the parties agree upon themselves, either before, or at the time of their conclusion of the contract of carriage. The CMR Convention allows the parties the possibility of agreeing a fixed delivery date, provided that the date requested by the consignor/shipper is accepted by the carrier. If they do, indeed, agree upon a fixed delivery date, this fact must be recorded on the Waybill.

\section{What does the CMR Consignment Note [Waybill] represent?}

This document represents prima facie evidence of the carriage of goods by road; performed on agreed terms. It is proof of effected delivery of the goods by the consignor/shipper; and it is necessary in respect of the given sales contract. Possession of the Waybill enables the holder, in case of necessity, to alter the destination of the goods. This would apply, for instance, if war, civil unrest or other type of catastrophe, manmade or natural, strikes the original destination. In case of alteration of destination of the goods, the change must be entered in the remarks section of the original Waybill form. 


\section{From when, and to when, is the Carrier responsible for the goods under the CMR Convention, and, are there limitations, or exemptions, placed by the Convention on the Carrier's Liabilities?}

The carrier's liability starts the moment he, or his authorised agent, takes over the goods; and ends upon, either, their safe delivery at their destination, or, in the case of more than one carrier being used, when each successive carrier takes them over for the next stage of carriage. Needless to say, the carrier, or his authorised agent, must check the condition of the goods prior to taking charge of them, and record any defects or damage he may find in them on the remarks section of the Waybill form; and this against the signature of the consgnor/shipper, or, previous carrier in the event of multi-stage carriage.

Whilst the carrier is responsible for any loss and/or damage to the goods which occurs during the period of their carriage; paragraph 17 of the CMR Convention specifies the special circumstances under which he is exempt from liability. In order to avail of the paragraph 17 exemption, the onus is on the carrier to prove the special circumstances apply to his case; otherwise he must make good any loss and/or damage which occured while the goods were in his charge.

\section{How to bring a claim under the CMR Convention.}

Upon the goods arriving at their destination, the receiver/consignee would be wise to check the condition of the goods before officially taking delivery of them. This is to preclude the carrier, in the event of loss and/or damage, disclaiming liability by saying that the loss and/or damage occured after the receiver/consignee had taken delivery of them, thus [wrongly] relieving the carrier of his responsibility to make good the loss and/or damage.

In the event of the receiver/consignee finding, upon inspection of them before taking them over, that the goods have indeed become the 'victims' of loss and/or damage in transit; he must, under article 30 of the CMR Convention, lodge his claim for compensation immediately; if the losss and/or damage is only apparent upon close inspection, and this after he has taken delivery of the goods; then the claim must be lodged, at the very latest, within 7 days of taking delivery of them.

\section{Compensation system under the CMR Convention}

Compensation is specified in article 23 of the CMR Convention and is limited to 8.33 S.D.R. [Special Drawing Rights] per kilo gross of the damaged and/or lost goods. Apart from that, compensation is granted for: freight, customs duty and other expenses, but only in case of total loss of the goods. Compensation is also granted in the case of delayed delivery, but only where this fact has caused damage to the goods; in which case it is limited to the level of the freight. 


\section{Conclusion}

Quite simply, this document, although it is a UN convention, is very important for the European Union. To illustrate this point, the EU guarantees freedom of movement of persons, goods and capital. No memberstate may pass any law which directly blocks these freedoms by, for instance, imposing onerous visa requirements [persons], tariffs or quotas [goods]; or, e.g. foreign exchange restrictions [capital]. Neither may memberstates pass any laws which indirectly block [doctrine of equivalent effect] these freedoms; i.e. protecting certain professions for their own nationals [persons], banning certain imports on health grounds [goods] and, e.g., very high charges for banking services [capital]. So, from this we can just some of the ways EU law facilitates free trade and the smooth functioning of the internal market. However, if carriers were hampered in their work by uncertainty in the sphere of Liability for Goods in Transit; where a carriage transaction could be followed by a potentiallly ruinous lawsuit; there could be great reluctance on the part of business people to engage in the transport sector at all, while those who would do it, would charge very much for the service in order to cover any eventual legal costs. This would arguably have the equivalent effect blocking the freedom of movement of goods. However, the CMR Convention with its precise conditions of carriage and distribution of liability, plus its upward limitation and prescription of the steps to be taken in order to claim compensation gives the element of certainty so critical to the smooth running of the free,internal market of the EU.

\section{Bibliography}

This contribution was worked from the original source, namely the CMR Convention 1956. I am indebted to JUDr. Miroslav Subert, ICC, for his endless patient and kind support and words of encouragement, in addition to his practical advice on how to go about this project. I would also like to thank Doc. JUDr. Martin Boháček, CSc.; Department of European and Commercial Law, Faculty of International Relations, VSE; for his very generously agreeing to write a review of my article. All mistakes contained therein are mine alone.

Freight Carrier`s Liability under the CMR convention 1956. 


\title{
Freight Carrier`s Liability under the CMR Convention 1956
}

\section{Ian Quigley}

\begin{abstract}
This article attempts to address some of the ways the CMR Convention 1956 removes some of the legal uncertainty and blind spots from the whole endeavour of Transporting Goods by Road. It outlines the methods used in Road Transport for allocating liability,locating the most probable point in time when any Loss and/or Damage occured to the Goods in Transit. The article also, briefly, introduces the reader to the rather complex business of making a claim for damages and the time limit for initiating proceedings.
\end{abstract}

Key Words: Legal Certainty; CMR Convention; Loss and/or Damage; Consignor/Sender/ Shipper; CMR Consignment Note; Waybill; Contract of Carriage; Special Drawing Rights; Total Loss; Claim; Receiver/Consignee.

\section{Odpovědnost přepravce podle mezinárodní konvence CMR 1956}

\begin{abstract}
Abstrakt
Tento článek se snaží objasnit, jak mezinárodní konvence CMR z r. 1956 přinesla právní jistotu do silniční dopravy zboží. Pojednává o tom, o čem je tato konvence, jak funguje $\mathrm{v}$ praxi a osvětluje některé pojmy s nimiž dopravci zboží pracují dennodenně a s nimiž by se měl dobře informovaný zákazník (spotřebitel) jejich služeb seznámit. Samožrejmě, že nelze opomenout všechny významné otázky, jako např. kdo je odpovědný za škodu a/nebo ztrátu na zboží (v tomto kritickém momentu), jak uplatnit nároky, když jde o porušení práva a přirozeně i jaké jsou hranice odpovědnosti žalovaného. Na konci v odstavci 10 naleznete krátký výčet klíčových slov.

Klíčová slova: právní jistota; mezinárodní konvence CMR; ztráta a/nebo škoda; zasílatel/odesilatel/odesilatel zboží $\mathrm{k}$ přepravě po moři (dovozce či vývozce); nákladní list CMR; průvodka; smlouva o přepravě, práva ze směnky; totální ztráta; nárok; př́ijemce zboží.
\end{abstract}

